\title{
DOMESTIC VIOLENCE AGAINST WOMEN IN MARRIAGE AND FAMILY RELATIONS: WAYS OF REGULATION AND LEGAL SETTLEMENT IN UKRAINE
}

\author{
Olena A. Uliutina \\ PhD in Law, Associate Professor, \\ Professor of Department of Administrative and Financial Law, \\ National University of Life and Environmental Sciences of Ukraine \\ 15 Heroiv Oborony Str., Kyiv, Ukraine, 03041 \\ https://orcid.org/0000-0003-1982-9911 \\ ulutinaea@gmail.com \\ Olena V. Artemenko \\ PhD in Law, Associate Professor of Department of Administrative and Financial Law, \\ National University of Life and Environmental Sciences of Ukraine, \\ 15 Heroiv Oborony Str., Kyiv, Ukraine, 03041 \\ https://orcid.org/0000-0003-2041-8925 \\ artolena11@ukr.net \\ Yuliia V. Vyshnevska \\ $\mathrm{PhD}$ in Law, Associate Professor of Department Professor of Law, \\ Kyiv Cooperative Institute of Business and Law, \\ 18 M. Lomonosov Str., Kyiv, Ukraine, 02000 \\ https://orcid.org/0000-0001-9431-4147 \\ vyuliia22@gmail.com
}

Abstract. The article examines the problem of domestic violence against women in marriage and family relations, and also identifies ways for the legal regulation of this issue. It turns out that at present, violence against women is one of the main social mechanisms through which women are forced to occupy a subordinate position in comparison with men. Violence directed at women reflects the structure of subordination and power, the depth of the differences between the sexes. "Violence against women» according to UN documents means any act of violence committed on the basis of gender, which causes or may cause physical, sexual, psychological harm or suffering to a woman, as well as threats to commit such acts, coercion or arbitrary deprivation of liberty, whether in public or private life.

It is concluded that in order to minimize the spread of such a negative phenomenon among the population, it is worth: to ensure the conduct of educational trainings and seminars for specialists of services for women and family affairs, social work, medical and pedagogical workers, volunteers to identify and prevent this type of crime; to strengthen public participation in the development of mechanisms and information on crimes related to domestic violence against women; improve the improvement of the collection of 
information of actors implementing measures to prevent and counter domestic violence and gender-based violence and establish better communication and cooperation between different bodies; ensure that the public is adequately informed about preventive measures and the ability to respond to crimes of domestic violence against women.

Keywords: violence, domestic violence, woman, family, marriage and family relations, criminal responsibility, gender equality.

\section{INTRODUCTION}

In recent years, the public of Ukraine is increasingly concerned about the problem of domestic violence as one of the most painful social phenomena. The state has launched a broad social information campaign to raise awareness of the existing problem, is constantly working with government agencies, local authorities with NGOs to prevent and combat domestic violence, but a wide variety of forms and methods of abuse of women in families observed both in Ukraine and in different regions of the world.

Currently, violence against women is one of the main social mechanisms by which women are forced to occupy a subordinate position compared to men. Violence against women reflects the structure of subordination and power, the full depth of differences between the sexes. «Violence against women» according to UN documents means any act of violence committed on the basis of sex, which causes or may cause physical, sexual, psychological harm or suffering to a woman, as well as the threat of such acts, coercion or arbitrary imprisonment, whether in public or private life.

In the current conditions of Ukraine, violence against women in the family does not lose its relevance and requires further research and development of measures to combat this phenomenon.

\section{MATERIALS AND METHODS}

The article focuses on the legislative regulation of the protection of women from domestic violence. An important place in any study is occupied by its methods by which the goal of the study is achieved. Among the main methods that were used in the study we would like to highlight: comparative law, formal law and the method of alternatives. In the scientific legal literature, many scientific publications are devoted to this issue, which explore some aspects of violence against women, among the main ones are the works of such scientists and scientists: O. Bandurka, A. Blaga, V. Vitvytska, O. Dzhuzha, L. Zavadska, L. Kormich, L. Kryzhna, N. Lavrynenko, I. Lavrynchuk, K. Levchenko, L. Leontieva, L. Levitsky, O. Matvienko, T. Melnyk, T. Minka and others. 


\section{RESULTS}

According to official data, more than a thousand women die in Ukraine every year as a result of domestic violence. According to UNDP, approximately 1.8 million women in Ukraine suffer from physical domestic violence. Domestic violence is becoming a terrible norm today. The vast majority of women currently serving sentences for the murder of their husbands, sexual partners or relatives are women who have suffered systematic and prolonged violence.

Due to these figures, it is important to ensure the legal protection and protection of women from domestic violence.

In accordance with Art. 3 of the Constitution of Ukraine, a person, his life and health, honor and dignity, inviolability and security are recognized in Ukraine as the highest social value. Human rights and freedoms and their guarantees determine the content and direction of the state. The state is accountable to man for his activities. The establishment and protection of human rights and freedoms is the main duty of the state. In addition, the provisions of the Constitution of Ukraine establish guarantees for the protection of the family. According to Article 32, no one may be interfered with in his personal and family life, except as provided by the Constitution of Ukraine, and according to Part 3 of Article 27 of the Constitution of Ukraine, everyone has the right to protection other people from illegal encroachments (Constitution of Ukraine, 1996).

The first international legal instrument to define the concept of „violence against women" is the UN Declaration on the Elimination of Violence against Women (1993), in which the term „violence against women” is understood as any act of violence committed on the basis of gender. , which causes or may cause physical, sexual or psychological harm or suffering to women, as well as the threat of such acts, coercion or arbitrary deprivation of liberty, whether in public or private life (Declaration on the Elimination of Violence against Women, 1993). The Declaration also states that violence against women covers cases of physical, sexual and psychological violence that occur in the family.

The UN Model Legislation is the basis of the Law of Ukraine „On Prevention of Domestic Violence”, which was adopted by the Verkhovna Rada of Ukraine on 15.11.2001 (repealed on 07.01.2018), in which the State for the first time recognized the problem of domestic violence on legislative level. Where it was stated that "domestic violence is any intentional act of physical, sexual, psychological or economic orientation of one family member towards another family member, if these actions violate the constitutional rights and freedoms of the family member as a person and a citizen and cause him moral harm, harm to his physical or mental health" (On the prevention of domestic violence, 2001).

Trying to solve the problem of domestic violence, in December 2017 the Verkhovna Rada of Ukraine adopted the Law «On Prevention and Counteraction to Domestic Violence» (On Prevention and Counteraction to Domestic Violence, 2017), which proposes a new approach (using European standards) to combat this negative phenomenon in society.

Resolution of the Cabinet of Ministers of Ukraine "On Amendments to the Resolution of the Cabinet of Ministers of Ukraine dated 5.09.2007 № 1087" On Advisory Bodies on Family, Gender Equality, Demographic Development, Prevention of Domestic Violence and Combating Trafficking in Human Being», term „Domestic violence” has been replaced by 
„domestic violence”. defining acts (acts or omissions) of physical, sexual, psychological or economic violence committed in the family or within the place of residence or between relatives, or between a former or current spouse, or between other persons living together (lived) one family, but are not (were not) in a family relationship or in a marriage with each other, regardless of whether the person who committed (lived) lives in the same place as the victim, as well as threats committing such acts (On Prevention and Counteraction to Domestic Violence, 2017).

As F. Melikov defines, the key word of the term "domestic violence” is the word "domestic", which refers to the house, ie its etymological essence means „housing and people living in it”, it can be both family members and and other persons, the relationship that has developed in the house, which means that the territorial feature of this concept is decisive (Melikov, 2017).

T. Minka notes that for the qualification of Art. 126-1 of the Criminal Code of Ukraine (criminal liability for domestic violence is envisaged) it does not matter whether the offender lives at the time of the act in the same place as the victim. Very often domestic violence can occur after the breakup of family or other relationships, so the cohabitation of the victim and the offender is not required (Minka, 2019).

That is why the implementation of the concept of "domestic violence" as a separate type of criminal offense in the array of the criminal law of Ukraine provokes a lot of scientific discussions.

Malinovska T.M., notes that first of all, it concerns the duplication of the same concept of «domestic violence» in somewhat different interpretations in the provisions of the Law of Ukraine «On Prevention and Counteraction to Domestic Violence» and, in particular, in the Criminal Code of Ukraine. This approach of the legislator, on the one hand, seems justified, because it aims to emphasize the features of domestic violence as a criminal offense. Although, on the other hand, the existence of two different legal definitions of the same concept seems to be such that,

- first, it contradicts the rules of legislative technique;

- secondly, to some extent complicates the practice of

- applying the relevant provisions of the Criminal Code of Ukraine;

- thirdly, it does not contribute to the clarity of statistical

- accounting for the purpose of quantification of criminal offenses related to domestic violence, which, ultimately, does not contribute to adequate planning of measures in this direction of counteraction (Malinovskaya, 2020).

Therefore, we can conclude that although to date and certain

mechanisms of normative-legal regulation of counteraction to domestic violence against women are provided, however the mechanism of its application in practice needs to be refined.

At the same time, in order to form the main ways to minimize the spread of domestic violence against women, it is necessary to pay attention to the factors that provoke it.

Researchers in the study of this problem examine in detail the factors that cause domestic violence in general and violence against women in particular (Dzhuzha, Opryshko, Kulik, 2005), and distinguish the following: 
- legal (attitude to violence as an internal family problem, not as a negative social phenomenon, to family members - as property due to lack of legal awareness);

- psychological (stereotypes of behavior);

- pedagogical (lack of culture of behavior - legal, moral, civil, aesthetic, economic, labor);

- social (tensions, conflicts, violence in society, promotion of violence in the media as a model of behavior);

- socio-pedagogical (lack of conscious parenthood, family values in society, a positive model of family life on the basis of gender equality, family education based on the rights of the child);

- economic (material deprivation, lack of decent living conditions, along with lack of conditions for employment, earning money, economic dependence, unemployment);

- physiological and medical (hormonal disorders, metabolism, speed of reactions, taking stimulant drugs, diseases of the nervous system, etc.);

- political (adherence to gender stereotypes, insufficient priority of family problems and gender equality, attention to motherhood and childhood, and not to the family as a whole, lack of attention to parenthood, men);

- socio-medical (lack of reproductive culture in the population, responsible parenting, family doctors, alcoholism, drug addiction, aggression, etc.). (Zaporozhtsev, Labun, Zabroda, 2012).

Such factors provoke special vigilance on the part of legislative and executive authorities to develop certain mechanisms to combat such a negative phenomenon. In this regard, the following measures were envisaged, which can be related to the problem of detecting crimes related to domestic violence:

- The first of them is to form a list of indicators for the central executive authorities to take into account cases of domestic violence and gender-based violence. An indicator of its implementation is starting from 2019 - the formation of a list of indicators for accounting by central executive bodies of cases of domestic violence and gender-based violence and the constant transfer of information about them to the Ministry of Social Policy of Ukraine;

- The second measure is to improve the mechanisms for identifying, documenting, responding to, investigating cases of domestic and gender-based violence against women and girls, and bringing perpetrators to justice. The indicator is the implementation in 2019 of the Ministry of Internal Affairs, the Ministry of Social Policy, the Ministry of Justice, the National Police and the Prosecutor General's Office (with consent) to improve mechanisms for identifying, documenting, responding, investigating cases of domestic violence and gender-based violence against women and girls. (Ierusalimov I.O., Ierusalimov V.I., 2019).

Thus, the resolution of the Cabinet of Ministers of March 20, 2019 № 234, approved the procedure for the formation, maintenance and access to the Unified State Register of cases of domestic violence and gender-based violence. The Register shall contain information (separately for each case) on: the case of violence, the victim and the measures taken to provide him with assistance, starting from the time and date of receipt of the application, notification of violence, personal data and information on free legal aid to the victim person; 
data on the offender, personal contact information, and the application of the prescribed measures, the court-approved probation program for the offender (according to the authorized bodies for probation), etc. (Resolution of the Cabinet of Ministers of Ukraine, 2019).

At the same time, due to the considerable work of law enforcement, legislative and executive authorities, the issue of mass spread of domestic violence against women is not decreasing, which is confirmed by annual statistics.

Introducing measures of legal liability (criminal in particular), first of all, it is necessary to address the issue of preventive measures and outreach to the population of Ukraine on the negative consequences of the spread of domestic violence, including against children.

\section{CONCLUSION}

Thus, based on the study, it is possible to say that the Ukrainian legislation has strengths and weaknesses in terms of practical experience in detecting offenses related to domestic violence.

In order to minimize the spread of such a negative phenomenon among the population should:

- to provide training and seminars for specialists in services for women and family, social work, medical and pedagogical workers, volunteers to detect and prevent this type of crime;

- strengthen public participation in the development of mechanisms and information on crimes related to domestic violence against women;

- to improve the organization of information collection of entities implementing measures to prevent and combat domestic and gender-based violence and to establish better communication and cooperation between different bodies;

- ensure that the public is properly informed about preventive measures and opportunities to respond to crimes related to domestic violence against women.

\section{REFERENCES}

Constitution of Ukraine (1996) with the following changes and additions). Retrieved from http://zakon1. rada.gov.ua/cgibin/laws/main.cgi?nreg= 254\% EA\% 2F96\% 2D\% E2\% F0

Declaration on the Elimination of Violence against Women (1993) proclaimed by Resolution 48/104 Gen.

UN Assembly of 20 Dec. 1993. Retrieved from http://zakon.rada.gov.ua/laws/show/995_506

On the prevention of domestic violence: the law of Ukraine (2001) № 2789-III. Retrieved from http://

zakon.rada.gov.ua/cgi-bin/laws/main.cgi?nreg=2789-14

On Prevention and Counteraction to Domestic Violence: Law of Ukraine (2017) № 2229-VIII. Retrieved from http://zakon5.rada.gov.ua/laws/show/2229-19

Melikov, F.A. (2017). Criminal law and criminological measures to combat domestic violence. Thesis of Cand. jurid. science 12.00.08. Moskow.

Minka, T. (2019). Separation of criminal and administrative liability for committing domestic violence. National juridical journal of theory and practice, 2, 98-101.

Malinovskaya, T.M. (2020). Domestic violence: regarding the meaningful content of the term. Our Law, 3, 85-91. Retrieved from: https://orcid.org/0000-0002-7713-7617. 
Legal and criminological principles of prevention of domestic violence: textbook (2005) / edited by M. Dzhuzha, I.V. Opryshko, O.G. Kulik. Kyiv.

Domestic violence and the activities of law enforcement agencies to overcome it (2012): a teaching method. book. compiler: Zaporozhtsev A.V., Labun A.V., Zabroda D.G. and others. Kyiv.

Ierusalimov, I.O., Ierusalimov, V.I. (2019). Peculiarities of detection of criminal offenses related to domestic violence. ScienceRise: Juridical Science, 4 (10), 49-55.

Procedure for formation, maintenance and access to the Unified State Register of Cases of Domestic Violence and Gender-Based Violence: Resolution of the Cabinet of Ministers of Ukraine (2019) № 234. March 20. Retrieved from https://zakon.rada.gov.ua/laws/main/234-2019-\%D0\%BF (access date April 2, 2021). 